\title{
DAMPAK KEBERADAAN TEMPAT PEMBUANGAN AKHIR TERHADAP KONDISI LINGKUNGAN DAN SOSIAL DI MASYARAKAT (STUDI KASUS DESA KARANG REJO KOTA METRO LAMPUNG)
}

\author{
Diyan Ahmad Saputra ${ }^{1 *}$, Agus Setiawan ${ }^{1}$, Endro P. Wahono ${ }^{1}$, Gunardi Djoko Winarno ${ }^{1}$ \\ ${ }^{1}$ Jurusan Ilmu Lingkungan, Fakultas Pascasarjana, Universitas Lampung, Lampung \\ *e-mail: diyanahmadsaputra@gmail.com
}

Diterima: 24 Oktober 2020; direvisi: 25 Oktober 2020; disetujui: 27 Oktober 2020

\begin{abstract}
ABSTRAK
Pengelolaan Tempat Pembuangan Akhir (TPA) secara Open Dumping serta lokasi dan pengelolaan sampah yang kurang memadai menimbulkan dampak negatif bagi masyarakat. Kegagalan pengelolaan sampah di Kota Metro bukan hanya disebabkan kelemahan teknis, kurangnya dukungan finansial, lembaga pengelola yang kurang efisien, serta sistem yang kurang tepat dapat menyebabkan Gangguan Mental Emosional (GME) serta permukiman padat penduduk, daerah kumuh, ventilasi yang buruk, bangunan rumah yang rusak, dinding rumah yang lembab dan berjamur, hingga keberadaan hama di sekitar rumah dapat menyebabkan kecemasan hingga gangguan jiwa. Peneliti mengevaluasi keberadaan TPA di 23 karang Rejo Kota Metro, agar keberadaan TPA dapat sesuai dengan ketentuan aturan yang berlaku. Metode penelitian yang digunakan adalah kualitatif, peneliti menguraikan kata-kata menurut pendapat responden dengan deskriptif. Selain wawancara, untuk memperkuat data yang dicari, peneliti mengambil gambar dan melakukan observasi kepada masyarakat dengan interaksi antar masyarakat, bagaimana masyarakat menjalani kehidupan lingkungan dan sosial. Teknologi pembuangan sampah telah berkembang, salah satunya pengembangan dari metode pembuangan sampah adalah metode Sanitary Landfill, dengan model Reusable Sanitary Landfill (RSL). Cara kerja metode supply yaitu sampah ditumpuk dalam suatu lahan, kemudian lahan tempat sampah dipadatkan sebagai ground liner. Ground liner dilapisi dengan geomembran, lapisan ini yang akan menahan meresapnya lindi ke dalam tanah dan mencemari air tanah. Di atas lapisan Geomembran dilapisi lagi Geotextile yang berfungsi menahan kotoran sehingga tidak bercampur dengan air lindi. Keterbatasan perspektif dalam penelitian karena studi terletak pada kecilnya sampel, disarankan perlu melakukan penelitian lebih lanjut dengan membandingkan beberapa kasus dengan konsep yang berbeda.
\end{abstract}

\section{Kata Kunci: Tempat Pembuangan Akhir (TPA), Permukiman, Sampah \\ IMPACT OF LANDFILL ON ENVIRONMENTAL AND SOCIAL CONDITIONS IN THE COMMUNITY (CASE STUDY OF KARANG REJO VILLAGE METRO LAMPUNG CITY)}

\begin{abstract}
Open Dumping and inadequate landfill management and waste management have negative impacts on the community. Failure to manage waste in Metro City is not only due to technical weaknesses, lack of financial support, inefficient management agencies, and inappropriate systems can cause Emotional Mental Disorders (GME) as well as densely populated settlements, slums, poor ventilation, damaged house buildings, damp and moldy walls of houses, to the presence of pests around the house can cause anxiety to mental disorders. Researchers evaluated the presence of landfills in 23 Karang Rejo Metro cities, so that the existence of landfill can be in accordance with the prevailing rules. The research method used is qualitative, researchers decipher words in the opinion of respondents descriptively. In addition to interviews, to strengthen the data sought, researchers took pictures and made observations to the community with inter-community interactions, how people live environmental and social lives. Garbage disposal technology has developed, one of the development of the waste disposal method is the Sanitary Landfill method, with the Reusable Sanitary Landfill (RSL) model. The way the supply
\end{abstract}


method works is that the garbage is stacked in a land, then the garbage can is compacted as a ground liner. Ground liners are coated with geomembranes, this layer that will withstand the pervasiveness of lindi into the soil and contaminate groundwater. On top of the geomembrane layer is another geotextile that serves to hold the dirt so that it does not mix with lindi water. The limitations of perspective in the study because the study lies in the small sample, it is suggested it is necessary to do more research by comparing some cases with different concepts.

\section{Key words: Landfill (TPA), Settlements, Garbage}

\section{PENDAHULUAN}

Sampah adalah barang yang lazim ditemukan di semua wilayah di Indonesia, kelaziman tersebut membuat masyarakat terbiasa berdampingan dengan sampah, baik ketika di rumah maupun di luar rumah. Selain korupsi, sampah juga menjadi salah satu faktor permasalahan sosial kemasyarakatan terutama di daerah perkotaan (Lumongga, 2019). Akibat pengelolaan sampah yang tidak tepat, seringkali mengundang banjir sebagai agenda rutin disaat datangnya musim hujan, sampah yang menyumbat saluran drainase membuat air tidak mengalir dengan baik, sehingga air meluap membanjiri pemukiman warga. Kasus sosial kemasyarakatan lainnya yang diakibatkan oleh sampah adalah menurunnya kualitas lingkungan pada setiap periode, di lokasi pembuangan sampah, limbah yang berasal dari sampah dapat mendatangkan bahaya bagi makhluk hidup. Kemudian, aroma busuk yang menyengat dapat merusak aktivitas manusia, selain itu, dampak buruk lainnya yaitu membludaknya sampah mengakibatkan semakin sempit pemukinan warga, tentu dampak dari pembuangan sampah dapat merusak seluruh segmentasi kehidupan.

Pengelolaan Tempat Pembuangan Akhir (TPA) secara Open Dumping menimbulkan dampak negatif, terutama terhadap lingkungan dan masyarakat sekitar TPA. Pemilihan lokasi TPA yang tidak tepat dan sistem pembuangan terbuka akan menghasilkan produk sampingan berupa gas metana dan cairan lindi. Cairan lindi berpengaruh pada sifat-sifat air bawah tanah (Hadiwidodo dkk, 2012), seperti tingginya konsentrasi total padatan terlarut, konduktivitas elektrik, tingkat kekerasan, klorida (Mayasari \& Hastarina, 2018), Chemical Oxygen Demand (COD) (Sari dan Suyasa, 2015), nitrat dan sulfat (Mahyudin, 2017).

Lokasi dan pengelolaan sampah yang kurang memadai (pembuangan sampah yang tidak terkontrol) merupakan tempat berkembangnya beberapa organisme dan menarik bagi berbagai binatang, seperti lalat dan anjing yang dapat mendatangkan penyakit. Potensi bahaya kesehatan yang dapat ditimbulkan yaitu, penyakit diare (Irawan, 2013), kolera (Lesmana, 2004), tifus menyebar dengan cepat akibat virus yang berasal dari sampah (Dahlan \& Munawar, 2017), dampak dari pengelolaan yang tidak tepat dapat merusak dan mencemari air yang di konsumsi. Penyakit demam berdarah (haemorhagic fever) dapat juga meningkat dengan cepat di daerah yang pengelolaan sampahnya kurang memadai (Candra, 2010).

Kegagalan mengelola sampah kota bukan hanya disebabkan kelemahan teknis, kurangnya dukungan finansial, lembaga pengelola yang kurang efisien, serta sistemnya yang kurang sempurna (Yuswi dan Rahayu, 2019). Masyarakat adalah pelaku dan faktor utamanya yang menentukan berhasil atau kurang berhasilnya suatu kegiatan (Soma, 2010). Belum ditemukannya pemberian edukasi terhadap warganya tentang praktek memperlakukan sampah oleh pemerintah Kota Metro, semuanya terkesan dibiarkan apa adanya, dengan hanya mengandalkan pelayanan dinas terkait yang membidangi sampah, sampah tidak pernah dipisahkan berdasarkan kelas sampah, kemudian sampah dibiarkan menumpuk di kotak 
sampah, lalu dilakukan pengangkutan oleh petugas yang berasal dari dinas.

Berdasarkan proyeksi penduduk pada tahun 2018, wilayah kota Metro memiliki potensi $0,7 \mathrm{~kg} / \mathrm{hari}$ untuk menghasilkan sampah, jika dikalikan dengan jumlah penduduk asli Metro yang berjumlah sekitar 150.950 jiwa. Maka, masyarakat Metro menghasilkan sampah sebesar 105.665 $\mathrm{kg} / \mathrm{hari}$, pertanyaannya berapa jumlah sampah yang dihasilkan selama 1 tahun yang akan datang? Jika melihat informasi yang berasal dari Kementerian Lingkungan Hidup pada tahun 2026 izin operasional TPA sudah dalam masa batas waktu (Sekretaris Dinas Lingkungan Hidup kota Metro, 2020). Jika hal dibiarkan berlarutlarut maka akan menimbulkan resiko keberadaan sampah yang bertambah di kemudian hari.

Keberadaan TPA yang berada di lingkungan masyarakat, tepatnya di 23 Karang Rejo Kota Metro telah lama menghadapi persoalan, akibat pengelolaan sampah di TPA belum maksimal, nilai Estetika dan bau yang tak sedap membuat lingkungan masyarakat terasa tidak nyaman. Menurut salah satu responden, seringkali armada yang membawa sampah yang melewati pemukiman penduduk menambah kepadatan lalu lintas, serta bau yang dihasilkan cukup menyengat, hal ini membuat masyarakat harus tutup hidung ketika berada dekat armada pengangkut sampah. Masyarakat khawatir jika kasus ini dibiarkan berlarut-larut, resiko terjangkit penyakit lebih besar. Karena aroma yang tidak sedap cukup menyengat dan dampak lain yang akan datang ketika permasalahan tersebut tidak diselesaikan.

$$
\text { Keberadaan TPA di } 23 \text { Karang Rejo }
$$

Kota Metro, menjadi magnet bagi berkumpulnya pemulung liar yang berasal dari luar wilayah 23 Karang rejo Kota Metro (Amran, 2016). Jumlahnya pemulung liar cukup banyak, Menurut Mugianto (Ketua $R T, 2020)$, masyarakat disekitar cukup merasakan dampak keberadaan TPA, terutama tempat tinggalnya yang berdampingan langsung dengan para pemulung, setiap kali musim penghujan datang yang dikhawatirkan masyarakat adalah nyamuk demam berdarah, masyarakat di 23 Karang Rejo Kota Metro pernah mengalami terjangkit demam berdarah dengan kasus terbanyak.

Pembuangan sampah di TPA Karang Rejo Kota Metro masih menggunakan open dumping, metode ini kurang menguntungkan kualitas air tanah. Cara kerja sistem tersebut cukup sederhana, yaitu dengan menggali tanah dan melapisinya dengan tanah liat yang dihubungkan ke sasaran lain, yaitu: saluran gas dan air lindi (leachate) pada instansi pengolahan. Sistem pengolahan ini dapat mencemari air tanah karena pelindian air sampah atau air lindi. Air sampah akan mencemari air tanah ketika mengalami pembusukan sampah secara organik dengan meresap ke dalam tanah atau terbawa bersama air hujan yang menginfiltrasi kedalam tanah.

Secara Psikologis, lingkungan sangat mempengaruhi perilaku masyarakat. Salah satunya Negara Jepang, masyarakat Jepang memiliki kecenderungan menghindari diri dari kebiasaan membeli sesuatu yang dianggap tidak perlu. Karena menurut masyarakat Jepang perilaku konsumtif akan mempengaruhi lingkungan, kemudian seterusnya lingkungan akan mempengaruhi perilaku, hal itulah yang membuat masyarakat Jepang tidak menerapkan perilaku konsumtif (Sekretaris Dinas Lingkungan Hidup kota Metro, 2020). Akibat keterbatasan pengetahuan, rumah masyarakat yang berdampingan dengan TPA, perilaku masyarakat akan berpengaruh, terutama sanitasi dan cara memperlakukan sampah. Air genangan yang berada di drainase menjadi hal yang biasa ditemukan di belakang rumah, kemudian kebiasaan membakar sampah karena tempat tinggal tidak jauh dari TPA dan tidak ikut serta membayar retribusi sampah yang dihasilkan oleh masyarakat sekitar TPA Karang Rejo Kota Metro.

Mayoritas masyarakat sekitar TPA Karang Rejo Kota Metro berada dalam hidup garis kemiskinan, selain faktor 
ekonomi, faktor lingkungan juga mempengaruhi kebersihan tempat tinggal mereka, keadaan rumah yang cenderung tidak terawat, kumuh, dan kotor, karena masyarakat sudah terbiasa hidup dengan keadaan yang kotor. Keadaan masyarakat yang terbangung tidak memperlihatkan keadaan sosial yang inisiatif atau memiliki motivasi tinggi untuk terus berbenah diri. Kebanyakan masyarakat hidup dalam keadaan yang apatis.

Kondisi lingkungan yang dapat menyebabkan Gangguan Mental Emosional (GME) yaitu tinggal di pemukiman padat pEnduduk, daerah kumuh, ventilasi yang buruk, bangunan rumah yang rusak, dinding rumah yang lembab dan berjamur, hingga keberadaan hama (tikus mencit, semut, kelelawar, dan sebagainya) di sekitar rumah dapat menyebabkan kecemasan hingga gangguan jiwa (Dharmayanti, 2018). Tingginya resiko gangguan kesehatan mental emosional masyarakat pada permukiman tidak sehat, disebabkan masyarakat yang tinggal di permukiman tidak sehat merasa tidak nyaman dengan kondisi mereka sehingga menimbulkan GME (Novoa, 2015).

Gaya hidup masyarakat sekitar TPA Karang Rejo Kota Metro kurang baik, pergaulan remaja yang terlampau bebas karena berada di daerah pinggiran kota yang kurang mendapatkan perhatian. Kenakalan remaja seperti mengkonsumsi minuman keras, aksi premanisme, dan tindakan perkelahian antar kelompok remaja sudah menjadi aktivitas yang biasa ditemukan. Pro kontra tentang perilaku yang dipengaruhi oleh lingkungan yang tercemar sampah sangat disayangkan, di tengah kondisi pemerintah yang belum berhasil mengelola sampah yang makin hari makin menumpuk, berdampak pada masyarakat sekitar TPA Karang Rejo Kota Metro yang terkena imbasnya. Maka, peneliti mencoba mengangkat tema ini untuk mencari tahu seberapa pengaruhnya keberadaan TPA di areal permukiman warga, terutama 23 Karang Rejo Kota Metro.

\section{BAHAN DAN METODE}

Kawasan TPA berada di 23 Karang Rejo Kecamatan metro Utara Kota Metro, TPA merupakan sarana fisik untuk berlangsungnya kegiatan pembuangan akhir sampah berupa tempat yang digunakan untuk mengkarantina sampah kota secara aman (Yasa dan Dharma, 2013). TPA Kota Metro berada di tengah pemukiman masyarakat 23 Karang Rejo yang dapat ditempuh dengan berjalan kaki sekitar 500 meter dari rumah warga. Berdasarkan proyeksi 2018, sampah yang dihasilkan oleh masyarakat Kota Metro memiliki potensi 0,7 $\mathrm{kg} /$ hari untuk menghasilkan sampah, jika dikalikan dengan jumlah penduduk asli Metro yang berjumlah sekitar 150.950 jiwa. Maka, masyarakat Metro menghasilkan sampah sebesar $105.665 \mathrm{~kg} / \mathrm{hari}$

Kajian penelitian ini menggunakan metode penelitian kualitatif deskriptif (Umar, 2009). Dalam hal ini peneliti membawa daftar pertanyaan sebagai acuan dalam pengambilan data dari responden (Muhammad, 2008). Kemudian peneliti menguraikan kata-kata menurut pendapat responden apa adanya sesuai dengan pertanyaan penelitian. Selain itu untuk memperkuat data yang dicari, peneliti mengambil beberapa gambar dan melakukan observasi (Bisri, 2003). Observasi dilakukan dengan mengacu pada lembar observasi. Observasi yang dilakukan antara lain mengenai interaksi antar masyarakat, bagaimana masyarakat menjalani kehidupan lingkungan dan sosialnya.

Teknik pengumpulan data melalui wawancara yaitu dilakukan dengan cara komunikasi tatap muka narasumber dan wawancara ini adalah pengelola TPA 23 Karang Rejo Kota Metro, Ketua Dusun, Ketua RT, Ketua Paguyuban. Untuk menguji validasi data, peneliti menggunakan teknik triangulasi berdasarkan sumber, yaitu peneliti melakukan pemeriksaan terhadap keabsahan data yang telah kami peroleh dengan membandingkan dan melakukan observasi kembali pada narasumber lain. 


\section{HASIL DAN PEMBAHASAN}

Filosofi mendasar mengenai pengelolaan sampah, sesuai dengan ketetapan dalam undang-undang nomor 18 tahun 2008 tentang pengelolaan sampah, kini perlu perubahan cara pandang masyarakat mengenai sampah dan cara memperlakukan atau mengelola sampah. Cara pandang masyarakat pada sampah seharusnya tidak lagi memandang sampah sebagai hasil buangan yang tidak berguna. Sampah seharusnya dipandang sebagai suatu yang mempunyai nilai guna dan manfaat (Peraturan Undang-Undang Nomor 18 Tahun 2008). Peraturan pemerintah No. 81 tahun 2012 tentang pengelolaan sampah rumah tangga dan sampah sejenis sampah rumah tangga, maka praktek pengelolaan dan memanfaatkan sampah harus menjadi langkah nyata dalam proses pengelolaan sampah (Peraturan Undang-Undang Nomor 81 Tahun 2012).

Sumber sampah yaitu permukiman, daerah komersial/perkantoran yang menghasilkan sampah langsung diangkut ke TPA oleh armada yang bertugas, begitupun sampah kawasan industri yang terdiri dari non-B3 diangkut langsung oleh armada ke TPA. Sedangkan sampah B3 ditampung dan dikelola sendiri secara khusus (IPAL, incinerator, dan sebagainya) di tempat terpisah bersama dengan sampah-sampah B3 yang dihasilkan dari rumah sakit atau klinik praktek dokter. Kemudian, sampah yang dihasilkan dari jalan langsung dibawa oleh armada pengangkut sampah ke TPA, sampah yang dihasilkan akan dibakar dengan insinerator, pengomposan, daur ulang plastik, jika sampah-sampah yang tidak dapat dikelola maka akan bertumpuk begitu saja di TPA.

Keberadaan TPA 23 Karang Rejo Metro memiliki jarak kurang lebih 500 meter dari pemukiman masyarakat. Keadaan yang begitu dekat membuat aroma bau yang ditimbulkan tumpukan sampah mencemari lingkungan warga. Maka, peneliti mencoba membuat evaluasi terhadap keberadaan TPA di 23 karang Rejo Kota Metro, agar keberadaan TPA dapat sesuai dengan ketentuan aturan yang berlaku, sehingga pemilihan TPA tidak menimbul permasalahan dan dampak negatif yang dihasilkan dari TPA dapat diminimalisir.

Menurut Mugianto (Ketua RT, 2020), keberadaan TPA di 23 Karang Rejo Kota Metro menyebabkan kondisi sosial kemasyarakatan menjadi terganggu, stigma TPA kotor dan menjadi tempat berkembangnya penyakit sepertinya membuat warga di sekitar Karang Rejo sedikit terdiskriminasi, mulai dari layanan kesehatan/informasi kesehatan. Lebih lanjut, Mujiono (Kepala Dusun, 2020) menambahkan keberadaan TPA membangun stigma negatif dari warga lain terhadap masyarakat sekitar TPA, keberadaan anak muda sekitar TPA seakan dibebaskan oleh keluarga, faktor pendidikan, dan lingkungan sangat mempengaruhi perilaku masyarakat. Mulai dari pakaian, sikap, dan tindakan tidak beraturan. Zainal abidin (Ketua Paguyuban Karang Rejo, 2020), menambahkan Keberadaan TPA memiliki dampak negatif terhadap lingkungan, beberapa bulan yang lalu warga melakukan aksi protes dengan memblokade jalan masuk wilayah TPA. Karena, kondisi sampah yang meluap sampai ke jalan pemukiman warga dan pembakaran sampah yang dilakukan dapat dinilai sebagai kegagalan dalam pengelolaan sampah. Jika kita membandingkan dengan TPA yang ada di Surabaya, TPA yang dimilki Kota Metro sangat tertinggal. Surabaya dapat mengubah sampah harian menjadi listrik, sedangkan Kota Metro pengumpulan sampah yang dilakukan masih mengundang beragam permasalahan, permasalahan sosial yang dihadapi adalah kesehatan bagi masyarakat pemukiman sekitar TPA, jaminan kesehatan sepatutnya sudah selayaknya gratis bagi warga setempat. Namun, Pemerintah sepertinya belum berani mengambil langkah tersebut sebagai bentuk kompensasi terhadap dampak adanya keberadaan TPA.

Tempat sampah merupakan tempat yang paling ideal bagi pertumbuhan vektor penyakit terutama lalat dan tikus. Hal ini disebabkan dalam tempat sampah terdapat 
sisa makanan yang bervarian dan dalam jumlah yang banyak. Hal tersebut tentu akan menurunkan kualitas kesehatan lingkungan sekitarnya, penutupan sampah yang tidak dilakukan sesuai ketentuan sehingga siklus hidup lalat dari telur menjadi larva telah berlangsung sebelum penutupan dilaksanakan. Gangguan akibat lalat umumnya dapat ditemui sampai radius 1-2 $\mathrm{km}$ dari lokasi TPA.
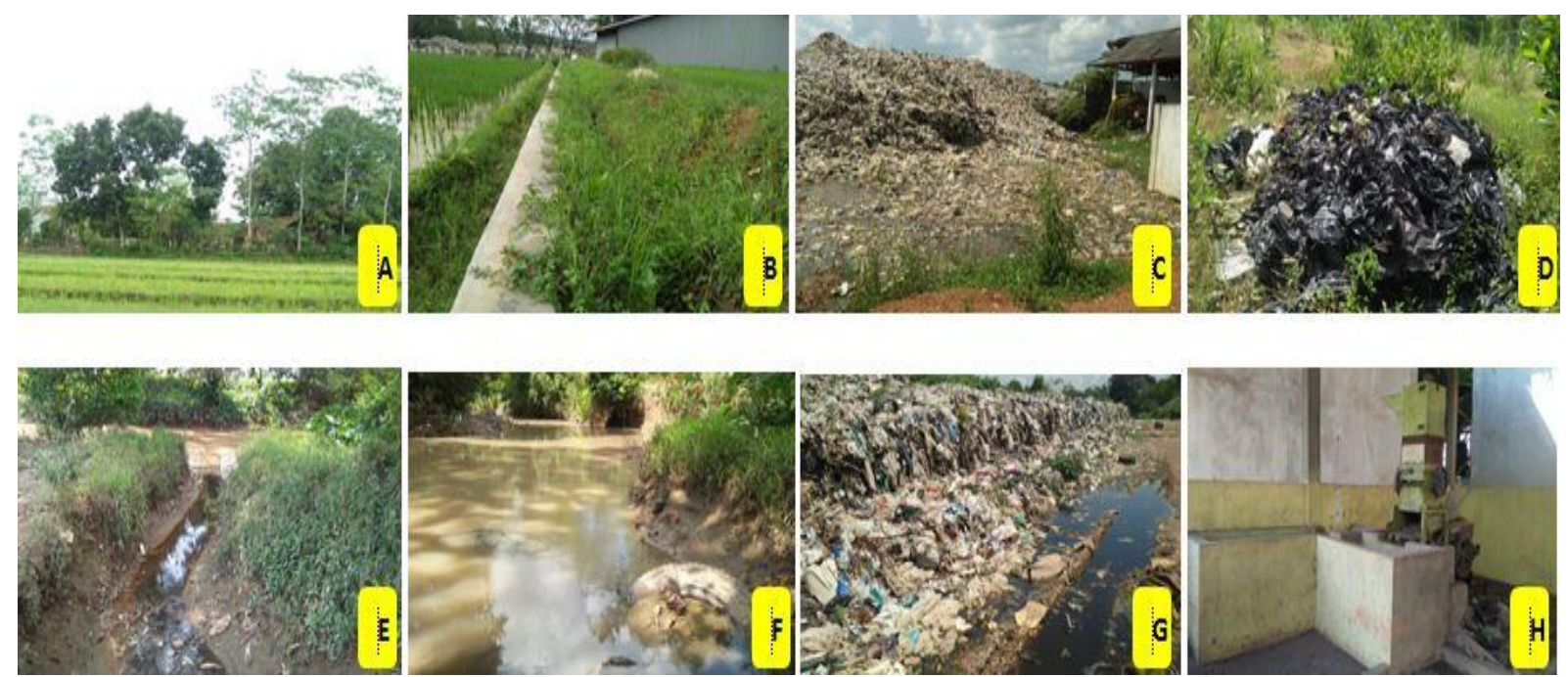

Gambar 1. A. Jarak TPA dengan pemukiman hanya sekitar 500 meter. B. Sawah milik warga berdampingan dengan TPA. C. Tumpukan sampah di TPA yang tidak dikelola. D. Sampah yang dihasilkan dari rumah sakit atau klinik praktek dokter. E.Pembuangan akhir TPA ke bantaran sungai terdapat endapan warna hitam dan mengeluarkan aroma tidak sedap. F. Sampah yang terbawa ke bantaran sungai sekitar TPA. G. Tumpukan sampah yang ditumpuk tanah dengan sistem land control mengeluarkan rembesan air yang mencemari air di bawah tanah. H. Mesin pengelola pupuk organic yang tidak berfungsi.

\section{Pada instalasi pengolahan terjadi} berupa pelepasan zat pencemar ke udara dari hasil pembuangan sampah yang tidak sempurna, diantaranya berupa: pertikular, SO x, NO x, hidrokarbon, $\mathrm{HCl}$, dioksin, dan sebagainya. Asap hasil pembakaran sampah seringkali timbul di TPA akibatnya membuat sampah menjadi bertumpuk baik secara sengaja maupun tidak. Produksi gas metan yang cukup besar dalam tumpukan sampah menyebabkan api sulit dipadamkan sehingga asap yang dihasilkan akan sangat mengganggu pemukiman sekitar TPA.

Lindi yang timbul di TPA sangat mungkin mencemari lingkungan sekitar yang berupa rembesan dari dasar TPA yang mencemari air tanah di bawah. Pada lahan yang terletak di kemiringan, kecepatan aliran air tanah akan cukup tinggi, sehingga dimungkinkan terjadi pencemaran terhadap sumur di setiap rumah yang berapa di pemukiman yang terletak pada elevasi yang lebih rendah. Pencemaran lindi dapat terjadi akibat pengaruh pengelolaan yang belum memenuhi syarat untuk dilakukan pembuangan ke badan air penerima, terutama air permukaan yang dengan mudah mengalami kekurangan oksigen terlarut sehingga mematikan biota yang ada.

Lapisan dasar TPA harus kedap air, hal ini dimaksudkan untuk menghambat daya serap lindi yang dihasilkan dalam pengelolaan sampah, sehingga tidak mencemari air tanah. Air tanah yang terkontaminasi oleh air lindi sangat tergantung pada permeabilitas tanah yang disyaratkan dalam kriteria. Jika tingkat kedalam air tanah tidak terpenuhi, maka diperlukan bantuan dari teknologi. Pengamatan terhadap permasalahan pengelolaan TPA, biaya pemusnahan sampah yang relatif tinggi di Indonesia, mengakibatkan meningkatnya pengguna 
metode pembuangan sampah dengan sistem open dumping.

Teknologi pembuangan sampah telah berkembang, salah satunya pengembangan dari metode-metode pembuangan sampah adalah metode Sanitary Landfill (Susanti dan Adhi, 2016), yaitu model Reusable Sanitary Landfill (RSL). RSL merupakan teknologi penyempurna sistem pembuangan sampah yang berkesinambungan dengan menggunakan metode supply ruang penampungan sampah (Diharto, 2009). Cara kerja metode supply adalah, sampah ditumpuk dalam suatu lahan, kemudian lahan tempat sampah dipadatkan sebagai ground liner (Rumbruren et al., 2015). Ground liner dilapisi dengan geomembran, lapisan ini yang akan menahan meresapnya lindi ke dalam tanah dan mencemari air tanah. Diatas lapisan Geomembran dilapisi lagi Geotextile yang berfungsi menahan kotoran sehingga tidak bercampur dengan air lindi.

Penggunaan lahan yang sangat terbatas, antara lain dapat dilakukan dengan cara mencari dan memilih alternatif yang sesuai dengan kebutuhan dan merencanakan sesuai dengan perubahan yang diinginkan. Pengaturan parameter kebisingan dan aroma tidak sedap serta estetika di dalam kriteria pemilihan lokasi TPA tidak berada pada tahap perencanaan, hal ini disebabkan bising dan aroma tidak sedap serta estetika lokasi. TPA 23 Karang Rejo Kota Metro dalam keadaan yang memprihatinkan, hal itu terlihat dari lingkungan dan perilaku masyarakat, selain kumuh dan kotor, aroma tidak sedap serta pencemaran saluran air ikut terkena dampaknya bagi masyarakat sekitar, hal itu menjadi sesuatu yang wajar bahkan masyarakat seperti tidak merasa khawatir sama sekali. Tentu ini menjadi sangat memprihatinkan, mengingat pemukiman menjadi tempat hidup dan berkembang. Hal yang fundamental tentang hak dan kewajiban masyarakat sebagai warga negara adalah mengakses dan menjaga lingkungan, karena mereka dilindungi hukum yaitu hak hidup layak.

\section{KESIMPULAN}

Permasalahan dalam pengelolaan sampah yang utama adalah sampah tidak mengalami proses pengolahan dan pengelolaan di TPA dengan sistem yang tepat (masih berfokus pada lahan urug). Pengelolaan TPA terpadu merupakan suatu kebutuhan penting bagi manusia. Keberadaan TPA sebagai tempat pembuangan akhir sampah sepatutnya diadakan dengan pertimbangan keamanan dari pencemaran lingkungan yang berdampak pada kesehatan masyarakat baik yang berdampak secara langsung maupun dampak mendatang. TPA tetap menjadi salah satu penanganan populer dalam permasalahan sampah, karena sangat sulit untuk memusnahkan atau mengurangi jumlah produksi sampah yang dihasilkan dari aktivitas manusia sehari-hari seiring dengan pertumbuhan populasi manusia yang semakin signifikan. Sulitnya mengelola TPA dengan benar dan dampak lingkungan dari keberadaan TPA mengharuskan pengelolaan TPA untuk menjalankan tugas dengan lebih baik, terutama mengolah sampah dengan cara daur ulang. Keterbatasan perspektif dalam penelitian karena studi terletak pada kecilnya sampel, disarankan perlu melakukan penelitian lebih lanjut dengan membandingkan beberapa kasus dengan konsep yang berbeda.

\section{UCAPAN TERIMA KASIH}

Ucapan terima kasih kepada seluruh rekanrekan yang telah membantu peneliti baik dari segi moril maupun materil sehingga penelitian ini dapat selesai dengan semestinya, kepada Yerri Noer Kartiko selaku Sekretaris Dinas Lingkungan Hidup Kota Metro dan kepada seluruh pejabat struktural setempat di 23 Karang Rejo Kota Metro yang telah memberikan informasi dan data yang dibutuhkan selama proses penelitian.

\section{DAFTAR PUSTAKA}

Abidin Z. (2020). Ketua Paguyuban Karang Rejo.

Amran Y. (2016). Pemanfaatan Limbah 
Plastik Untuk Bahan Tambahan Pembuatan Paving Block Sebagai Alternatif Perkerasan Pada Lahan Parkir Di Universitas Muhammadiyah Metro. Teknologi Aplikasi Konstruksi: Jurnal Program Studi Teknik Sipil. 4(2): 125-129.

https://doi.org/10.24127/tapak.v4i2.143

Bisri C.H. (2003). Penuntun Rencana Penelitian dan Pelaksana Skripsi Bidang Ilmu agamaIslam. Raja Grafindo Persada.

Candra A. (2010). Demam Berdarah Dengue: Epidemiologi, Patogenesis, dan Faktor Risiko Penularan. ASPIRATOR-Journal of Vector-Borne Disease Studies. 2(2): 110-119. http://ejournal2.litbang.kemkes.go.id/in dex.php/aspirator/article/view/1787

Dahlan A., dan Munawar A. (2017). Hubungan Sanitasi Lingkungan dan Faktor Budaya dengan Kejadian Tifus di Wilayah Kerja Puskesmas Lambur Kabupaten Tanjung Jabung Timur Tahun 2013. Jurnal Ilmiah Universitas Batanghari Jambi. 14(1): 95-101. https://doi.org/10.33087/jiubj.v14i1.31 2

Dharmayanti I. (2018). Pengaruh Kondisi Kesehatan Lingkungan Dan Sosial Ekonomi Terhadap Kesehatan Mental Di Indonesia. Jurnal Ekologi Kesehatan. 17(2): 64-74. https://doi.org/10.22435/jek.17.2.149.6 4-74

Diharto. (2009). Studi Perencanaan TPA Buluminung Kabupaten Penajam Paser Utara Dengan Sistem Sanitary Landfill. Jurnal Teknik Sipil Dan Perencanaan. 11(2): 191-200. https://doi.org/10.15294/jtsp.v11i2.172 7

Hadiwidodo M., Oktiawan W., Primadani A. R., Parasmita B. N., Gunawan I. (2012). Pengolahan Air Lindi Dengan Proses Kombinasi Biofilter Anaerob-aerob Dan Wetland. Jurnal Presipitasi: Media Komunikasi Dan Pengembangan Teknik Lingkungan. 9(2): 84-95. https://doi.org/10.14710/presipitasi.v9i 2.84-95

Irawan A.Y. (2013). Hubungan Antara Aspek Kesehatan Lingkungan Dalam PHBS Rumah Tangga Dengan Kejadian Penyakit Diare Di Kecamatan Karangreja Tahun 2012. Unnes Journal of Public Health. 3(1): 1-9. https://doi.org/10.15294/ujph.v2i4.305 8

Kartiko Y.N. (2020). Sekretaris Dinas Lingkungan Hidup kota Metro.

Lesmana M. (2004). Perkembangan Mutakhir Infeksi Kolera. Jurnal Dokter Trisakti. 23(3): 101-109. https://univmed.org/ejurnal/index.php/ medicina/issue/archive

Lumongga R.I. (2019). Tinjauan Kebijakan Lingkungan Hidup terhadap Standar Baku Pemilihan Lokasi Tempat Pembuangan Akhir Sampah. Sosial Ekonomi Pekerjaan Umum. 6(2): 109118.

http://jurnalsosekpu.pu.go.id/index.php /sosekpu/article/view/16

Mayasari R., Hastarina M. (2018). Optimalisasi Dosis Koagulan Aluminium Sulfat Dan Poli Aluminium Klorida (PAC) (Studi Kasus Pdam Tirta Musi Palembang). Integrasi: Jurnal Ilmiah Teknik Industri. 3(2): 2835.

https://doi.org/10.32502/js.v3i2.1273

Mahyudin R. P. (2017). Kajian Permasalahan Pengelolaan Sampah dan Dampak Lingkungan di TPA (Tempat Pemrosesan Akhir). Jukung (Jurnal Teknik Lingkungan). 3(1): 66-74. https://doi.org/10.20527/jukung.v3i1.3 201

Mugianto. (2020). Ketua RT.

Muhammad. (2008). Metodologi Penelitian Ekonomi Islam Pendekatan Kuantitatif. Rajawali Press.

Mujiono. (2020). Kepala Dusun.

Novoa A. (2015). How Substandard Dwellings And Housing Affordability Problems Are Associated With Poor Health In a Vulnerable Population During The Economic Recession Of 
The Late 2000s. International Journal For Equity In Health. 14(1): 1-11. https://doi.org/10.1186/s12939-0150238-z

Peraturan Undang-Undang Nomor 18 Tahun 2008.

Peraturan Undang-Undang Nomor 81 Tahun 2012.

Rumbruren A. A., Tarore R. C., Sember A. (2015). Evaluasi Kelayakan Lokasi Tempat Pembuangan Akhir Sampah Di Kecamatan Manokwari Selatan. Jurnal SPESIAL. $\quad 2(3)$ : 1-10. https://ejournal.unsrat.ac.id/index.php/s pasial/article/view/9973.

Sari S.D.M., Suyasa I.W.B., Mahardika I.G. (2015). Pemanfaatan Biosistem Tanaman Untuk Menurunkan Kadar Fenol, Amonia, Ion Klorida, dan COD Dari Proses Biodegradasi Air Limbah yang Mengandung Rhodamin B. Ecotrophic. $10(1)$ : 1-8. https://doi.org/10.24843/EJES.2016.v1 0.i01.p01.

Soma S. (2010). Pengantar Ilmu Teknik Lingkungan Seri: Pengelolaan Sampah Perkotaan. IPB Press.
Susanti E. Y., Adhi S., Manar D, G. (2016). Analisis Faktor Penghambat Penerapan Kebijakan Sanitary Landfill Di TPA Jatibarang Semarang Sesuai Dengan Undang-undang No. 18 Tahun 2008 Tentang Pengelolaan Sampah. Journal Of Politic And Government Studies. 2(3): 1-13. https://ejournal3.undip.ac. id/index.php/jpgs/article/view/12444

Umar H. (2009). Metode Penelitian Untuk Skripsi Dan Tesis Bisnis. Raja Grafindo Persada.

Yasa I.W., Dharma I.B.S., Sudipta I.K. (2013). Manajemen Risiko Operasional Dan Pemeliharaan Tempat Pembuangan Akhir (TPA) Regional Bangli Di Kabupaten Bangli. Jurnal Spektran. 1(2): 30-38. https://erepo.unud.ac.id/id/eprint/1648

Yuswi B.V., Rahayu P., Hardiana A. (2019). Faktor-Faktor Yang Mempengaruhi Kinerja Bank Sampah Di Kota Surakarta Berdasarkan Persepsi Masyarakat Pengguna Bank Sampah. Jurnal Pembangunan Wilayah Dan Perencanaan Partisipatif. 14(2): 124140. https://doi.org/10.1234/region. v14i2.22950. 